\title{
Coleoptera of the Penza region, Russia based on fermental crown trap
}

\author{
A.B. RUCHIN ${ }^{1, \boldsymbol{v}}$, L.V. EGOROV ${ }^{1,2}$, O.A. POLUMORDVINOV ${ }^{3}$ \\ ${ }^{1}$ Joint Directorate of the Mordovia State Nature Reserve and National Park «Smolny», 431660, Mordovia Republic, Rusia. \\ "e-mail: ruchin.alexander@gmail.com. \\ ${ }^{2}$ State Nature Reserve «Prisursky», Lesnoi, 9, Cheboksary, 428034, Chuvash Republic, Russia \\ ${ }^{3}$ Penza State University. Ulitsa Krasnaya, 40, Penza, 440026, Penza Oblast, Rusia \\ Manuscript received: 26 January 2021. Revision accepted: 25 March 2021.
}

\begin{abstract}
Ruchin AB, Egorov LV, Polumordvinov OA. 2021. Coleoptera of the Penza region, Russia based on fermental crown trap). Biodiversitas 22: 1946-1960. There are the results of processing the material of the 2019-2020 studies on Coleoptera from the Penza region, Russia. The surveys were carried out using fermental crown traps in various habitats on the territory of 18 districts of the region. In total, 18 traps were installed in 2019 and 96 traps - in 2020. During the research, 5,577 specimens were collected and recorded. Ninety-seven species from 19 families were found, of which 43 species are new to the Penza region. The most diverse families are Cerambycidae (24 species) and Elateridae (11 species). Species from the families Nitidulidae (3281 specimens), Scarabaeidae (1497 specimens), and Cerambycidae (453 specimens) predominated in the traps. A list of species is given, indicating references and information on biology. New data is given for 4 species included in the Red Data Book of the region (Protaetia fieberi, Protaetia speciosissima, Gnorimus variabilis, Purpuricenus globulicollis).
\end{abstract}

Keywords: Coleoptera, fauna, rare species, biology, fermental crown traps, Penza region

\section{INTRODUCTION}

At the beginning of the XXI century, the conservation of biological diversity is considered one of the main global challenges of humanity and as the most important condition for the stability of ecological systems (Robin 2011; Grubert 2018). Biodiversity supports society in ecological, economic, cultural and spiritual fields. Despite the fact that biodiversity has a significant impact on the daily life and development of society, the world faces permanent irretrievable losses of individual species and entire ecosystems. Species and ecosystems, as well as the threats they face, vary across and within geographic regions (Myers et al. 2000; Hooper et al. 2005; Huang et al. 2018; Ahissa et al. 2020; de Lima et al. 2020; Feng et al. 2020; King et al. 2021). It is important to maintain a high level of diversity for many reasons, including the fact that the natural world brings to human life. Therefore, in recent years, nature conservation and biodiversity conservation have been viewed as the same issue (Mathews 2016; Uwalaka et al. 2018; Kestemont 2019; Mellard et al. 2019; Cicort-Lucaciu 2020; Kroll et al. 2020; Wang et al. 2020).

Coleoptera fauna inventory and regional faunal reports are conducted in many regions of Russia in order to preserve biodiversity (Storozhenko et al. 2002; Budaev et al. 2019; Prokin et al. 2019; Ruchin et al. 2019b; Rozhnov et al. 2019; Sazhnev et al. 2019; Bondarenko et al. 2020; Egorov et al. 2020a; Sergeev 2020; Zemoglyadchuk et al. 2020). A significant part of the research is devoted to the study and conservation of rare and unique Coleoptera species, the loss of which can lead to a decrease in ecosystem biodiversity (Frolov 2013; Bardiani et al. 2017; Redolfi De Zan et al. 2017; Polevoi et al. 2018; Ruchin and
Egorov 2018a,b,c; Tomaszewska et al. 2018; Ruchin and Khapugin 2019; Dedyukhin 2020).

The Penza region is located on the Russian Plain and occupies the middle and western part of the Volga Upland. Coleoptera of this region is studied intensively and in recent years a number of interesting studies have been published (Levkovich and Levkovich 2006; Pronina 2010; Bashinsky and Osipov 2019; Danilevsky et al. 2019; Ruchin et al. 2019c). However, all of them are based on standard methods of studying Coleoptera fauna, while special methods provide additional and sometimes unexpected data (Dodds 2014; Rukavina et al. 2018; Barros et al. 2020; Philips et al. 2020; Touroult and Witté 2020). This publication examines the Coleoptera biodiversity of the Penza region, which was studied in 2019-2020 using fermental crown traps.

\section{MATERIALS AND METHODS}

\section{Study area}

The Penza region is located at the junction of forest, forest-steppe and steppe natural zones. The terrain is a hilly plain. The central and eastern part of it is occupied by the western slope of the Volga upland, and the western part by the Oka-Don lowland. The highest and most hilly surface is located in Zasurye, in the bend of Sura. SurskMoksha hill is situated in the Northern areas in the West region, the Oka-Don plain is in the South $(150-180 \mathrm{~m}$ a.s.l.). The region length from East to West is $190 \mathrm{~km}$ (from $42^{\circ} 40^{\prime}$ to $47^{\circ} \mathrm{E}$ ), and $110 \mathrm{~km}$ from North to South $\left(53^{\circ} 20^{\prime}\right.$ to $\left.52^{\circ} 20^{\prime} \mathrm{N}\right)$. The terrain is elevated, slightly hilly, with deep flowing wide ancient river valleys, with many 
ravines and gullies. Heights of less than $100 \mathrm{~m}$ a.s.l. are located in the Vysha River valley in the northwest of the region. In terms of hydrology, the region is divided into two basins of approximately equal areas: the Don Basin (the Khoper River and the Vorona River), and the Volga Basin (the Sura, Kadada, and Moksha Rivers). The watershed of the basins runs along the Kerensky-Chembar upland. The climate is temperate continental, strongly influenced by the Atlantic. The lowest temperatures were recorded on the plains in January $\left(-43\right.$ to $\left.-45^{\circ} \mathrm{C}\right)$ and the highest ones in July $\left(38-39^{\circ} \mathrm{C}\right)$.

There is a diverse natural vegetation cover in the southwestern part of the Volga Upland, which is determined by the location of the territory at the junction of forest and steppe vegetation zones. The forest cover of the region is approximately $21.4 \%$. Meadow (northern) steppes and broad-leaved forests are the zonal vegetation types of the research region. The border of the forest - steppe transition coincides with the border of the replacement of some geological deposits by others. Small north-western part of the region is a transition zone of mixed and broad-leaved forests. The southwestern part of the region should be attributed to the zone of steppes (Kuritsyn and Mardensky 1991).

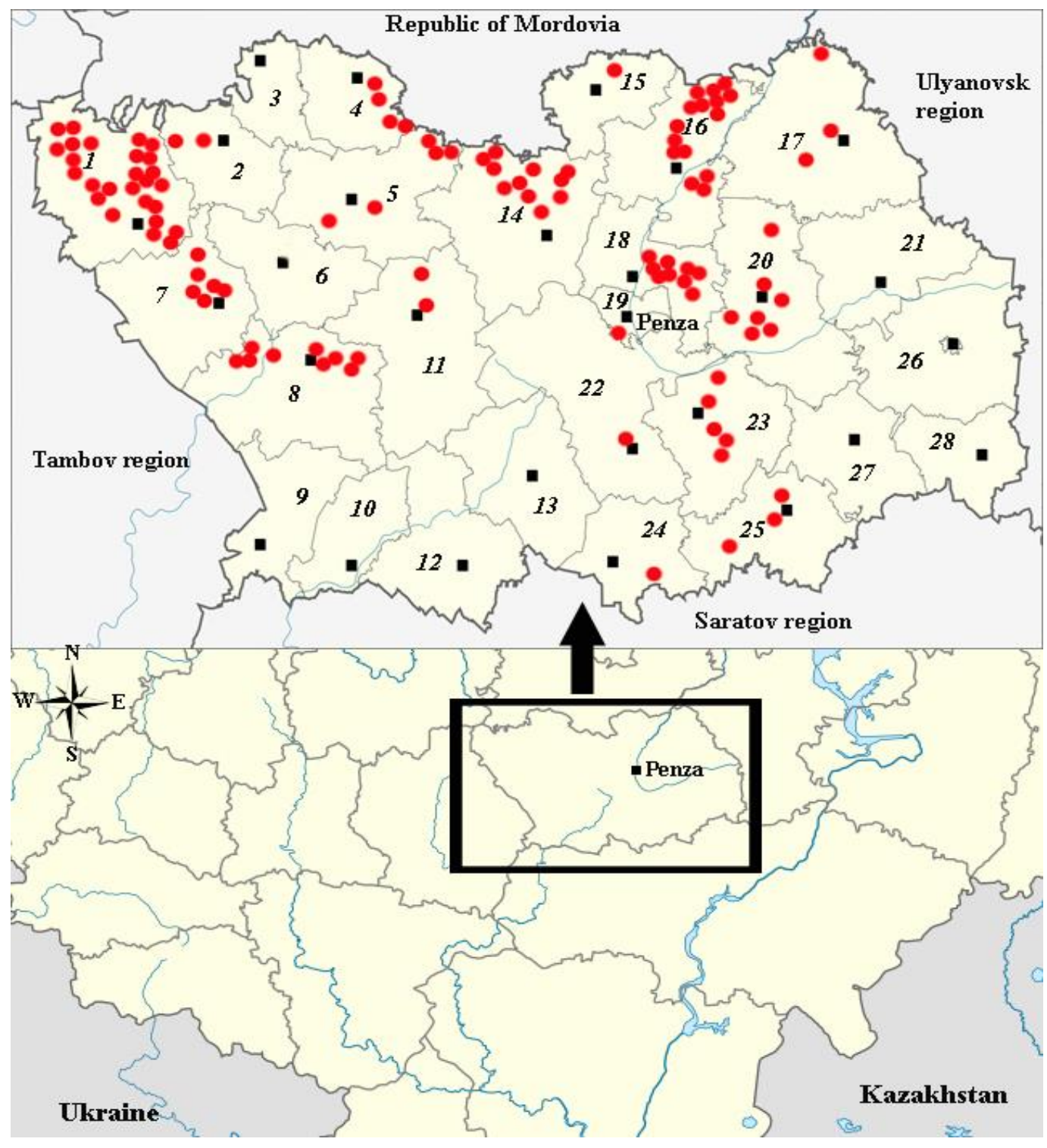

Figure 1. The studied areas within the territory of the Penza region. The red dots indicate the collection points. The numbers indicate districts of the Penza region: 1 - Zemetchino district; 2 - Vadinsk district; 3 - Spassk district; 4 - Narovchat district; 5 - Nizhny Lomov district; 6 - Pachelma district; 7 - Bashmakovo district; 8 - Belinsky district; 9 - Tamala district; 10 - Bekovo district; 11 - Kamenka district; 12 - Serdobsk district; 13 - Kolyshlei district; 14 - Mokshan district; 15 - Issa district; 16 - Lunino district; 17 - Nikolsk district; 18 - Bessonovka district; 19 - Penza district; 20 - Gorodishche district; 21 - Sosnovoborsk district; 22 - Kondol district; 23 Shemysheika district; 24 - Malaya Serdoba district; 25 - Lopatino district; 26 - Kuznetsk district; 27 - Russky Kameshkir district; 28 Neverkino district. The black squares indicate the administrative centers of the districts. 


\section{MATERIALS AND METHODS}

The material was collected in $2019-2020$ by the first author in 18 districts of the Penza region, with the use of fermental crown traps (Figure 1). Two versions of traps were used in the crowns of trees. In the first case, the trap was a 5-liter plastic container with a window cut out on one side at a distance of $10 \mathrm{~cm}$ from the bottom (Ruchin et al. 2020). Fermented beer with the addition of sugarcontaining components (honey, jam and sugar) was used as bait. In 2020, a different type of bait trap was additionally used (Jalas 1960). There was a mixture of white, red wine and beer with added sugar as an attractive substrate. As a fixative, $96 \%$ ethyl alcohol was added. The traps were installed in the tree crowns at a height of 7 to $10 \mathrm{~m}$ from the surface. The exposure (duration of installation) of the traps ranged from 7 to 15 days. Table 1 shows the geographical characteristics of each research site, with the dates of the trap installation and the coordinates of the area. During the collection, a total of 5,577 Coleoptera specimens were collected and recorded. The studied material is stored in the collection of the Mordovia State Nature Reserve (Pushta village).

Table 1. Geographical characteristics of research sites, dates of trap expositions, and coordinates of research sites in the Penza region

\begin{tabular}{|c|c|c|c|c|}
\hline District & Locality & Habitat & Date & Coordinates $\left({ }^{\circ} \mathbf{N},{ }^{\circ} \mathbf{E}\right)$ \\
\hline \multirow[t]{6}{*}{ Bashmakovo } & Spirtzavod & Willow thickets & 1-15.VII.2020 & $53.3039,42.8993$ \\
\hline & Ermakovsky & Deciduous forest & 1-15.VII.2020 & $53.2646,42.9438$ \\
\hline & Ermakovsky & Deciduous forest & 15-29.VII.2020 & $53.2643,42.9415$ \\
\hline & Troitskoe & Deciduous forest & 1-15.VII.2020 & $53.2695,42.8233$ \\
\hline & Timiryazevo & Deciduous forest & 1-15.VII.2020 & $53.2766,42.8445$ \\
\hline & Ermakovsky & Deciduous forest & 15-29.VII.2020 & $53.2636,42.9423$ \\
\hline \multirow[t]{8}{*}{ Belinsky } & Staraya Kashtanovka & Deciduous forest & 29.VII-12.VIII.2020 & $53.0076,43.3022$ \\
\hline & Belinsky & Deciduous forest & 29.VII-12.VIII.2020 & $52.9961,43.4096$ \\
\hline & Volchkovo & Deciduous forest & 29.VII-12.VIII.2020 & $52.9785,43.4718$ \\
\hline & Studenka & Deciduous forest & 1-15.VII.2020 & $53.0092,43.1431$ \\
\hline & Poim & Aspen forest & 1-15.VII.2020 & $53.0107,43.2258$ \\
\hline & Shiryaevo & Deciduous forest & 15-29.VII.2020 & $52.9913,43.0237$ \\
\hline & Studenka & Deciduous forest & 1-15.VII.2020 & $53.0092,43.1431$ \\
\hline & Studenka & Deciduous forest & 15-29.VII.2020 & $53.0114,43.1733$ \\
\hline \multirow{8}{*}{ Bessonovka } & Nikolaevka & Mixed forest & 25.VI.-10.VII.2020 & $53.3326,45.1850$ \\
\hline & Kolos & Mixed forest & 25.VI.-10.VII.2020 & $53.3219,45.1980$ \\
\hline & Sosnovka & Mixed forest & 25.VI.-10.VII.2020 & $53.2957,45.2839$ \\
\hline & Stepanovka & Mixed forest & 10-24.VII.2020 & $53.2432,45.4449$ \\
\hline & Era & Mixed forest & 25.VI.-10.VII 2020 & $53.3683,45.1419$ \\
\hline & 3 km SE Era & Mixed forest & 25.VI.-10.VII 2020 & $53.3509,45.1692$ \\
\hline & Aleksandrovka & Mixed forest & 25.VI.-10.VII 2020 & $53.3075,45.2242$ \\
\hline & 4,5 km E Grabovo & Deciduous forest & 25.VI.-10.VII.2020 & $53.3732,45.1087$ \\
\hline \multirow[t]{7}{*}{ Gorodishche } & Sadovka & Deciduous forest & 10-24.VII.2020 & $53.2509,45.4994$ \\
\hline & $5 \mathrm{~km}$ E Gorodishche & Deciduous forest & 10-24.VII.2020 & $53.2755,45.5817$ \\
\hline & Mordovsky Ishim & Deciduous forest & 10-24.VII.2020 & $53.1928,45.6410$ \\
\hline & Gorodishche & Deciduous forest & 19.VIII-1.X.2020 & $53.2872,45.6916$ \\
\hline & Mozharka & Deciduous forest & 10-24.VII.2020 & $53.2180,45.6610$ \\
\hline & Peschanka & Deciduous forest & 19.VIII-1.X.2020 & $53.4761,45.7848$ \\
\hline & Telegino & Deciduous forest & 19.VIII-1.X.2020 & $53.3911,45.7274$ \\
\hline \multirow[t]{2}{*}{ Kamenka } & Klychishche & Deciduous forest & 29.VII-12.VIII.2020 & $53.1559,43.9405$ \\
\hline & Kamenka & Deciduous forest & 29.VII-12.VIII.2020 & $53.2144,44.0255$ \\
\hline Kondol & Kondol & Deciduous forest & 7-20.VIII.2020 & $52.8198,44.9891$ \\
\hline \multirow[t]{3}{*}{ Nikolsk } & Mais & Deciduous forest & 6-19.VIII.2020 & $53.8684,45.9690$ \\
\hline & Pavlovka & Mixed forest & 6-19.VIII.2020 & $53.8772,45.8861$ \\
\hline & Nikolsk & Mixed forest & 19.VIII-1.X.2020 & $53.7188,45.9846$ \\
\hline Malaya Serdoba & Komarovka & Deciduous forest & 7-20.VIII.2020 & $52.4693,45.2564$ \\
\hline \multirow[t]{3}{*}{ Lopatino } & Chardym & Deciduous forest & 24.VII.-7.VIII.2020 & $52.6307,45.7793$ \\
\hline & Lopatino & Deciduous forest & 24.VII.-7.VIII.2020 & $52.6012,45.7774$ \\
\hline & Kozlovka & Deciduous forest & 24.VII.-7.VIII.2020 & $52.5670,45.7333$ \\
\hline \multirow[t]{5}{*}{ Lunino } & Lesnoi Viyas & Mixed forest & 22.V.-12.VI 2020 & $53.7649,45.4637$ \\
\hline & Staraya Kutlya & Deciduous forest & 12-25.VI.2020 & $53.6612,45.3479$ \\
\hline & Lunino & Willow thickets & 12-25.VI.2020 & $53.5688,45.2663$ \\
\hline & Karaulovka & Mixed forest & 12-25.VI.2020 & $53.5440,45.2529$ \\
\hline & Zasurskoe & Mixed forest & 12-25.VI. 2020 & $53.5390,45.2426$ \\
\hline
\end{tabular}




\begin{tabular}{|c|c|c|c|c|}
\hline & Ivanyrs & Mixed forest & 12-25.VI.2020 & $53.5705,45.3185$ \\
\hline & Bolshoi Viyas & Birch forest & 18.IV-9.V.2020 & $53.7985,45.4928$ \\
\hline & Lesnoi Viyas & Mixed forest & 18.IV-9.V.2020 & $53.7648,45.4636$ \\
\hline & Kazachiya Peletma & Mixed forest & 18.IV-9.V.2020 & $53.7548,45.4441$ \\
\hline & Bolshoi Viyas & Birch forest & 9-22.V.2020 & $53.7986,45.4927$ \\
\hline & Lesnoi Viyas & Mixed forest & 9-22.V.2020 & $53.7649,45.4637$ \\
\hline & Kazachiya Peletma & Mixed forest & 22.V-12.VI.2020 & $53.7547,45.4441$ \\
\hline & Posopnaya Peletma & Mixed forest & 22.V-12.VI.2020 & $53.7317,45.4115$ \\
\hline & Lomovka & Mixed forest & 22.V-12.VI.2020 & $53.6858,45.3678$ \\
\hline & Ivanyrs & Mixed forest & 12-25.VI.2020 & $53.5736,45.3133$ \\
\hline \multirow[t]{11}{*}{ Mokshan } & Krasnoe Poltso & Mixed forest & 15-29.VI.2019 & $53.4629,44.6488$ \\
\hline & Krasnoe Poltso & Mixed forest & 29.VI-12.VII.2019 & $53.4627,44.6494$ \\
\hline & Zasechnoe & Deciduous forest & 15-29.VI.2019 & $53.5721,44.7071$ \\
\hline & $5 \mathrm{~km} \mathrm{SW}$ Sumarokovo & Deciduous forest & 15-29.VI.2019 & $53.4890,44.6867$ \\
\hline & Chernozerie & Deciduous forest & 29.VI-12.VII.2019 & $53.5884,44.3344$ \\
\hline & Dolgorukovo & Deciduous forest & 29.VI-12.VII.2019 & $53.6099,44.2715$ \\
\hline & Gorodishche & Deciduous forest & 29.VI-12.VII.2019 & $53.6345,44.2534$ \\
\hline & Alekseevka & Deciduous forest & 29.VI-12.VII.2019 & $53.6406,44.3468$ \\
\hline & Solovievka & Willow thickets & 29.VI-12.VII.2019 & $53.6175,44.3549$ \\
\hline & Elizino & Deciduous forest & 6-24.VIII.2019 & $53.6018,44.4999$ \\
\hline & Pichuevka & Pine forest & 6-24.VIII.2019 & $53.5816,44.4896$ \\
\hline \multirow[t]{4}{*}{ Narovchat } & Barabanovka & Deciduous forest & 12-24.VII.2019 & $53.7536,43.8806$ \\
\hline & Kazenchik & Deciduous forest & 12-24.VII.2019 & $53.7501,43.8915$ \\
\hline & Skanovo & Deciduous forest & 12-24.VII.2019 & $53.8790,43.7354$ \\
\hline & Krasnyi Vostok & Mixed forest & 12-24.VII.2019 & $53.8195,43.7475$ \\
\hline \multirow[t]{5}{*}{ Nizhny Lomov } & Virga & Deciduous forest & 29.VII-12.VIII. 2020 & $53.4429,44.0567$ \\
\hline & Sorokino & Deciduous forest & 12-25.VIII.2020 & $53.6217,43.3675$ \\
\hline & Andreevka & Deciduous forest & 29.VII.-12.VIII.2020 & $53.3920,44.0896$ \\
\hline & Iva & Deciduous forest & 12-24.VII.2019 & $53.7186,43.9433$ \\
\hline & Svetlorechenka & Deciduous forest & 12-24.VII.2019 & $53.6232,43.9770$ \\
\hline Penza & Salovka & Deciduous forest & 7-20.VIII.2020 & $53.1155,44.7803$ \\
\hline \multirow[t]{5}{*}{ Shemysheika } & Russkaya Norka & Deciduous forest & 24.VII.-7.VIII.2020 & $52.7800,45.3981$ \\
\hline & Verkhozim & Deciduous forest & 24.VII.-7.VIII.2020 & $52.7467,45.4192$ \\
\hline & 4 km S Novaya Yaksarka & Deciduous forest & 10-24.VII.2020 & $52.9523,45.3929$ \\
\hline & Shemysheika & Deciduous forest & 10-24.VII.2020 & $52.9230,45.3937$ \\
\hline & Azrapino & Deciduous forest & 24.VII.-7.VIII.2020 & $52.7408,45.6054$ \\
\hline \multirow[t]{2}{*}{ Vadinsk } & Ovcharnye Vyselki & Deciduous forest & 12-25.VIII.2020 & $53.6218,42.9984$ \\
\hline & Artamas & Deciduous forest & 12-25.VIII. 2020 & $53.5684,42.8940$ \\
\hline \multirow[t]{29}{*}{ Zemetchino } & Pashkovo & Mixed forest & 9-19.VI.2020 & $53.6364,42.4362$ \\
\hline & Morsovo & Mixed forest & 9-19.VI.2020 & $53.7191,42.3516$ \\
\hline & $5 \mathrm{~km}$ SE Morsovo & Mixed forest & $9-19$. VI.2020 & $53.6966,42.3866$ \\
\hline & 4 km NW Pashkovo & Mixed forest & $9-19$. VI.2020 & $53.6811,42.4021$ \\
\hline & Pashkovo & Mixed forest & 9-19.VI.2020 & $53.6666,42.4264$ \\
\hline & $3 \mathrm{~km}$ SE Chernoyar & Mixed forest & 19.VI.-1.VII 2020 & $53.7795,42.2896$ \\
\hline & 3 km S Vyazemka & Mixed forest & 15-28.IV.2020 & $53.5839,42.6818$ \\
\hline & Desyatyi Oktyabr & Deciduous forest & 15-28.IV.2020 & $53.5503,42.6887$ \\
\hline & Malaya Izhmora & Deciduous forest & 15-28.IV.2020 & $53.5409,42.7092$ \\
\hline & $3 \mathrm{~km} \mathrm{~S} \mathrm{Vyazemka}$ & Deciduous forest & 15-28.V.2020 & $53.5839,42.6816$ \\
\hline & Desyatyi Oktyabr & Deciduous forest & $15-28 . V .2020$ & $53.5504,42.6887$ \\
\hline & Malaya Izhmora & Deciduous forest & 15-28.V.2020 & $53.5410,42.7092$ \\
\hline & Desyatyi Oktyabr & Deciduous forest & 28.V-9.VI.2020 & $53.5505,42.6888$ \\
\hline & Malaya Izhmora & Deciduous forest & 28.V-9.VI.2020 & $53.5411,42.7093$ \\
\hline & Vyazemka & Deciduous forest & 28.V-9.VI.2020 & $53.5888,42.6852$ \\
\hline & Sychevka & Deciduous forest & 28.V-9.VI.2020 & $53.5916,42.4626$ \\
\hline & Pashkovo & Mixed forest & 28.V-9.VI.2020 & $53.6363,42.4362$ \\
\hline & Saltykovo & Deciduous forest & 28.V-9.VI.2020 & $53.6134,42.4487$ \\
\hline & Vyazemka & Deciduous forest & 9-19.VI.2020 & $53.5887,42.6852$ \\
\hline & Morsovo & Mixed forest & 19.VI.-1.VII 2020 & $53.7194,42.3517$ \\
\hline & 3 km NW Morsovo & Mixed forest & 19.VI.-1.VII 2020 & $53.7655,42.3027$ \\
\hline & Chernoyar & Mixed forest & 19.VI.-1.VII 2020 & $53.7921,42.2825$ \\
\hline & Krasnaya Dubrava & Deciduous forest & 28.IV.-15.V.2020 & $53.6782,42.6334$ \\
\hline & Vyazemka & Deciduous forest & 28.IV.-15.V.2020 & $53.5983,42.6764$ \\
\hline & Desyatyi Oktyabr & Deciduous forest & 28.IV.-15.V.2020 & $53.5505,42.6888$ \\
\hline & Malaya Izhmora & Deciduous forest & 28.IV.-15.V.2020 & $53.5411,42.7093$ \\
\hline & Sychevka & Deciduous forest & 28.V.-9.VI.2020 & $53.5915,42.4625$ \\
\hline & Vyazemka & Deciduous forest & 9-19.VI.2020 & $53.5883,42.6852$ \\
\hline & Saltykovo & Deciduous forest & 19.VI.-1.VII.2020 & $53.5914,42.4621$ \\
\hline
\end{tabular}


Leonid Egorov identified Coleoptera. The system of Coleoptera, the volume and nomenclature of most taxa are accepted mainly according to the "Catalogue of Palaearctic Coleoptera" (Löbl and Smetana 2007, 2011, 2013; Löbl and Löbl 2015, 2016; Danilevsky 2020; Iwan and Löbl 2020). Data on the occurrence of species and species diversity were analyzed. To compare the occurrence of species, the number of species sightings was determined in relation to the total number of trap exposures. When specifying the biology of the species, we used our own data and observations in nature.

\section{RESULTS AND DISCUSSION}

\section{Results}

A total of 97 species from 20 families have been recorded. Unfortunately, the Coleoptera biodiversity of the Penza region is still very poorly studied. Scattered data (Dyukin 1912; Dmitriev 1926; Anufriev et al. 1999; Bokhovko and Stoiko 2002; Levkovich and Levkovich 2006; Polumordvinov and Glebov 2010; Pronina 2010; Lebyazhinskaya 2012; Dobrolyubova 2013) suggests that more than 1,000 species are currently known. However, this species diversity is very small and according to our objective data, the beetle fauna should number at least 3000 species. This conclusion can be made if we compare the state of the fauna of the regions bordering the Penza region. For example, in the Republic of Mordovia, about 3,300 species of Coleoptera are already known (Ruchin and Egorov 2018b, 2019a,b; Ruchin et al. 2018, 2019a; Kazantsev et al. 2019; Alekseev and Ruchin 2020; Egorov et al. 2020b; Zemoglyadchuk et al. 2020). In our research, the use of crown traps allowed us to detect 43 new species for the Penza region at once. This indicates a poor knowledge of the beetle fauna of the region and the use of new research methods in this case is very effective.

The most diverse families are Cerambycidae (24 species) and Elateridae (11 species) (Fig. 2). Most of the families were represented in our collections by single species. Species from the families Nitidulidae $(3,281$ specimens), Scarabaeidae (1,497 specimens), and Cerambycidae (453 specimens) predominated in the traps. The remaining families in the collections are represented by less than a hundred specimens, and some by single individuals (Fig. 3). Below, there is a list of Coleoptera species found using fermental crown traps. The list for each species contains references to literature data from the territory of the Penza region (if there is a reliable indication), the place of collection of the material, indicating the number of localities and the number of collected or recorded specimens ("Material"), original data on the biology of the species. The names of the new species for the fauna of the Penza region are marked with a single asterisk (*). In the "Material" section, the locale number is indicated (see Table 1), while the number of instances found is indicated in parentheses.

\section{List of species}

Order COLEOPTERA Linnaeus, 1758

Suborder ADEPHAGA Schellenberg, 1806

Family CARABIDAE Latreille, 1802

Harpalus xanthopus winkleri (Schauberger, 1923)

Literature data: Lebyazhinskaya (2012).

Material: 54 (1).

Biology. It is typical for broad-leaved and mixed forests, spruce forests. It falls into the crown traps accidently.

Limodromus assimilis (Paykull, 1790)

Literature data: Levkovich and Levkovich (2006); Lebyazhinskaya (2012).

Material: 11 (1).

Biology. In the region, it is a common species, found in mixed and deciduous forests. It falls into the crown traps accidently.

\section{Suborder POLYPHAGA Emery, 1886 \\ Family SILPHIDAE Latreille, 1806}

Dendroxena quadrimaculata (Scopoli, 1771)

Literature data: Levkovich and Levkovich (2006).

Material: 46 (4); 56 (3); 102 (1); 105 (1).

Biology. An active predator. Main habitats: deciduous and mixed forests, pine forests with birch undergrowth. It is a common species. It is often found on the leaves of shrubs and undergrowth of trees, on forest roads.

\section{*Necrodes littoralis (Linnaeus, 1758)}

Material: 6 (4); 18 (1); 32 (1); 39 (1); 41 (1); 42 (1); 61 (16); 80 (2); 83 (5).

Biology. A necrobiont. It is noted that beetles feed on Diptera larvae located on carrion. We caught them in crown traps. A single species appeares during collecting insects at night on UV light. This species is also attracted by insects that have died in traps.

Nicrophorus humator (Gleditsch, 1767)

Literature data: Bokhovko and Stoiko (2002).

Material: 42 (1).

Biology. It prefers forest habitats. The biology is similar to the previous species.

Nicrophorus interruptus (Stephens, 1830)

Literature data: Bokhovko and Stoiko (2002)

Material: 2 (2); 42 (3); 81 (1); 82 (3).

Biology. It is necrophage, was found only in forest biotopes (on the edges). A single species appeares during collecting insects at night on UV light. The biology is similar to the previous species.

*Nicrophorus sepultor (Charpentier, 1825)

Material: 42 (1).

Biology. It was caught simultaneously with the previous three species in one trap on the edge of a deciduous forest that turns into a meadow biotope. 
Nicrophorus vespillo (Linnaeus, 1758)

Literature data: Bokhovko and Stoiko (2002); Levkovich and Levkovich (2006).

Material: 82 (1).

Biology. One of the most common species of the family. It is often found in many biotopes. It rarely appears in crown traps.

\section{Oiceoptoma thoracicum (Linnaeus, 1758)}

Literature data: Levkovich and Levkovich (2006).

Material: 67 (1).

Biology. One of the most common species of the family. It is often found on the soil in many biotopes.

\section{Family STAPHYLINIDAE Latreille, 1802}

*Quedius dilatatus (Fabricius, 1787)

Material: 4 (1); 6 (2); 8 (1); 11 (5); 12 (1); 14 (4); 15 (2); 17 (11); 18 (16); 19 (10); 20 (1); 21 (6); 22 (1); 23 (7); 27 (1); 28 (1); 33 (1); 34 (3); 37 (1); 40 (2); 41 (3); 42 (1); 63 (3); 65 (1); 71 (2); 79 (1); 81 (2); 83 (1).

Biology. It is found in mixed and deciduous forests, pine forests. The species is related to the nests of Vespa crabro Linnaeus, 1758, where its larvae feed on Diptera larvae in the fragments of the nests (Salnitska and Solodovnikov 2019).

\section{Family SCARABAEIDAE Latreille, 1802}

Cetonia aurata (Linnaeus, 1758)

Literature data: Dmitriev (1926); Anufriev et al. (1999);

Levkovich and Levkovich (2006); Dobrolyubova (2013).

Material: 2 (1); 3 (11); 5 (25); 6 (2); 7 (1); 14 (4); 26

(1); 29 (1); 42 (1); 43 (1); 47 (1); 54 (2); 58 (2); 59 (12); 60

(2); 73 (15); 74 (3); 75 (2); 77 (3); 81 (3); 82 (5); 101 (54); 102 (1); 103 (19); 112 (2); 113 (10).

Biology. The most common type of flower chafers in the region, found in most biotopes. Beetles can often be found on flowering plants and leaking tree sap, and larvae have been found in the decaying wood of oak petiolate.

\section{Gnorimus variabilis (Linnaeus, 1758)}

Literature data: Dmitriev (1926); Levkovich and Levkovich (2006); Polumordvinov and Monakhov (2003); Red Data Book of Penza Region (2019).

Material: 64 (2); 83 (1).

Biology. A rare species. It is confined to deciduous forests, where it adheres to areas with Quercus robur, and is also found in pine forests. They fly from the beginning of June to the end of July, larvae are found in the rotten wood of oak and other deciduous trees, pine.

\section{Protaetia affinis (Andersch, 1797)}

Literature data: Dmitriev (1926); Levkovich and Levkovich (2006)

Material: 101 (2); 112 (4); 114 (1).

Note. These are new findings of a very rare and local species, previously known in 1910 within the modern territory of Penza. A detailed report on the distribution of the species in the European part of Russia is in press.

\section{Protaetia fieberi (Kraatz, 1880)}

Literature data: Polumordvinov and Monakhov (2003); Red Data Book of Penza Region (2019); Ruchin et al. (2019c).

Material: 1 (1); 2 (5); 3 (19); 4 (4); 5 (10); 6 (28); 8 (1); 10 (2); 14 (13); 16 (1); 19 (1); 23 (2); 26 (2); 27 (5); 29 (6); 40 (21); 41 (3); 42 (23); 47 (2); 58 (5); 59 (6); 60 (3); 61 (7); 64 (5); 66 (1); 68 (3); 69 (3); 70 (5); $71(1) ; 72(3) ; 73$ (1); 77 (4); 79 (7); 80 (1); 81 (9); 82 (3); 83 (5); 87 (1); 89 (1); 90 (4); 91 (1); 100 (2); 101 (6); 102 (2); 103 (1); 104 (4); 113 (4); 114 (3).

Biology. This is a local species, confined to broadleaved and mixed forests, sometimes found in floodplains of deciduous forests. Imagos are active from the end of May to August.

\section{Protaetia marmorata (Fabricus, 1792)}

Literature data: Dmitriev (1926); Levkovich and Levkovich (2006).

Material: 2 (1); 3 (26); 4 (47); 5 (13); 6 (39); 8 (1); 9 (4); 10 (8); 11 (3); 14 (26); 15 (1); 16 (4); 18 (4); 21 (3); 22 (3); 23 (4); 24 (3); 26 (2); 27 (12); 28 (5); 29 (26); 30 (1); 31 (1); 32 (27); 33 (4); 34 (2); 36 (7); 37 (3); 38 (1); 40 (9); 41 (12); 43 (5); 44 (19); 42 (8); 45 (5); 46 (19); 47 (13); 48 (4); 54 (5); 56 (6); 58 (50); 59 (18); 60 (4); 61 (13); 62 (5); 63 (1); 64 (13); 65 (1); 66 (5); 67 (7); 68 (15); 69 (6); 70 (2); 71 (4); 72 (13); 73 (11); 74 (1); 75 (6); 76 (7); 77 (38); ) 78 (1); 79 (5); 80 (1); 81 (1); 82 (1); 83 (9); 84 (1); 86 (4); 87 (10); 88 (28); 89 (25); 90 (12); 91 (11); 95 (3); 98 (2); 99 (10); 100 (83); 101 (59); 102 (11); 103 (14); 104 (17); 105 (1); 106 (1); 107 (2); 111 (2); 112 (7); 113 (19); 114 (25).

Biology. It is found in deciduous and mixed forests, in parks, forest protection strips and other biotopes. Larval development takes place in the hollows of dead deciduous trees for three years. In beer traps, this is the most common species.

Protaetia cuprea volhyniensis (Gory \& Percheron, 1833) (previously was indicated as Protaetia metallica (Herbst, 1782))

Literature data: Dmitriev (1926); Levkovich and Levkovich (2006).

Material: 2 (2); 5 (1); 14 (1); 19 (3); 32 (2); 41 (1); 42 (1); 54 (1); 55 (2); 60 (1); 61 (2); 66 (1); 68 (1); 69 (1); 82 (1); 90 (1); 101 (5); 103 (1); 107 (4); 113 (1).

Biology. It is common for deciduous and mixed forests, oak forests, and floodplains. This is a local species. Beetles usually fly in May-August. Larvae are found in decaying trunks of oak.

\section{Protaetia speciosissima (Scopoli, 1786)}

Literature data: Dmitriev (1926); Polumordvinov and Monakhov (2003); Levkovich and Levkovich (2006); Red Data Book of Penza Region (2019).

Material: 2 (1); 3 (2); 6 (12); 14 (5); 24 (1); 27 (2); 29 (1); 32 (1); 40 (4); 41 (4); 42 (2); 58 (1); 62 (1); 68 (1); 70 (1); 72 (1); 77 (1); 79 (1); 112 (4); 113 (2).

Biology. The species is confined to broad-leaved and deciduous forests with oak, and is found in floodplains of 
rivers. Beetles feed on the woody sap of oak and willow trees. Imagos are caught from the end of May to the beginning of September.

\section{Family BUPRESTIDAE Leach, 1815}

Anthaxia quadripunctata (Linnaeus, 1758)

Literature data: Levkovich and Levkovich (2006).

Material: 13 (1).

Biology. It is common for pine and mixed forests, complex forests. This is a local and common species. It flies in late May-July. The larvae develop in dead trunks of pine trees.

\section{Dicerca alni (Fischer von Waldheim, 1824)}

Literature data: Levkovich and Levkovich (2006).

Material: 67 (1).

Biology. It is common in floodplain forests and blackwoods. The species is not uncommon but is local. It flies in June and July. Larvae are found in dead trunks of alder.

\section{Family ELATERIDAE Leach, 1815}

Agrypnus murinus (Linnaeus, 1758)

Literature data: Anufriev et al. (1999); Levkovich and Levkovich (2006).

Material: 44 (1); 45 (2); 47 (1); 48 (1); 55 (2); 107 (1).

Biology. This is one of the main species of agricultural pests in the region. It lives on sandy loam soils.

Ampedus cinnabarinus (Eschscholtz, 1829)

Literature data: Levkovich and Levkovich (2006).

Material: 90 (1); 107 (1).

Biology. It is found in old-growth pine forests, mixed forests with birch and spruce (Ruchin et al. 2018).

*Ampedus nigroflavus (Goeze, 1777)

Material: 101 (1).

Biology. It is found in deciduous and mixed forests (Ruchin et al. 2018).

*Ampedus pomorum (Herbst, 1784)

Material: 19 (2); 48 (2); 57 (1); 107 (1).

Biology. It is a common species for mixed, pine, and deciduous forests. Often it can be found in the old burned areas (Ruchin et al. 2018).

*Ampedus sanguinolentus (Schrank, 1776)

Material: 107 (4).

Biology. It is a common species for mixed, deciduous forests with aspen (Ruchin et al. 2018).

\section{*Limonius minutus (Linnaeus, 1758)}

Material: 32 (1).

Biology. The species is found in mixed, floodplain broad-leaved forests, pine forests with spruce, birch, aspen (Ruchin et al. 2018).
*Melanotus castanipes (Paykull, 1800)

Material: 88 (1).

Biology. It is found in mature spruce forests with pine and birch, deciduous forests, floodplain deciduous forests with a predominance of aspen, mixed forests, pine forests with spruce (Ruchin et al. 2018).

*Melanotus villosus (Geoffroy, 1785)

Material: 102 (1).

Biology. It is an inhabitant of deciduous forests (Ruchin et al. 2018).

Prosternon tessellatum (Linnaeus, 1758)

Literature data: Anufriev et al. (1999).

Material: 11 (2); 19 (1); 48 (13); 54 (1); 55 (12); 57 (4); 100 (2); 104 (1); 107 (6).

Biology. This is one of the main pests of agriculture in the region, it lives on forest edges and in gullies. It is often found on flowering plants. It is found in many forest ecosystems.

Selatosomus aeneus (Linnaeus, 1758)

Literature data: Anufriev et al. (1999); Levkovich and Levkovich (2006).

Material: 18 (1).

Biology. This is one of the main pests of agriculture in the region, it lives on podzolic soils. It is often found in clearings, edges of various forests.

\section{Family CANTHARIDAE Imhoff, 1857 (1815) \\ *Cantharis livida (Linnaeus, 1758)}

Material: 101 (1); 107 (1).

Biology. It is found in different biotopes: on the edges and clearings of pine forests, alder forests, mixed forests, in floodplain meadows. It is rarely found in crown traps. It is confined to herbaceous plants.

*Cantharis nigricans (O.F. Müller, 1776)

Material: 44 (2); 103 (1).

Biology. This is one of the most frequently encountered species of this family. It lives in a wide variety of biotopes of open and closed landscapes. It is rarely found in crown traps. It is confined to herbaceous plants.

*Cantharis pellucida (Fabricius, 1792)

Material: 87 (1).

Biology. This is a common type for edges, clearings in forests, parks, and gardens. It is rarely found in crown traps. It is confined to herbaceous plants.

*Rhagonycha nigriventris (Motschulsky, 1860)

Material: 43 (1).

Biology. This is a common species. It is found in mixed and deciduous forests, pine forests and spruce forests with pine and birch. It is rarely found in crown traps. It is confined to herbaceous plants. 
Family DERMESTIDAE Latreille, 1804

*Attagenus schaefferi (Herbst, 1792)

Material: 54 (1).

Biology. It an anthophily species. It is often caught in crown traps.

*Dermestes murinus (Linnaeus, 1758)

Material: 102 (1).

Biology. It is found in a mixed forest at the edge of a clearing (our data).

* Globicornis emarginata (Gyllenhal, 1808)

Material: 54 (1).

Biology. It is found in a mixed forest. According to some data, it was collected from oak firewood (Merkl 1993). Larvae were found on the dead polypore fungi (Nikitsky and Schigel 2004).

*Trogoderma glabrum (Herbst, 1783)

Material: 98 (1); 101 (1).

Biology. It is considered a cryptogenic species for Europe. It is found near colonies of solitary bees and wasps, where its larvae feed on animal remains (OrlovaBienkowskaja 2019).

\section{Family PTINIDAE Latreille, 1802}

*Dorcatoma robusta (A. Strand, 1938)

Material: 95 (1).

Biology. It develops in bracket fungi in different types of forests (Nikitsky and Schigel 2004).

\section{Family CLERIDAE Latreille, 1802}

*Thanasimus femoralis (Zetterstedt, 1828)

Material: 56 (1).

Biology. It lives in coniferous and mixed forests, is found on the bark of trunks and logs of spruce and pine trees. It's a predator (Nikitsky and Schigel 2004).

\section{Family MELYRIDAE Leach, 1815}

Cordylepherus viridis (Fabricius, 1787)

Literature data: Anufriev et al. (1999).

Material: 86 (1).

Biology. This is a common species. It is found in mixed and deciduous forests. It is rarely found in crown traps.

*Dasytes fusculus (Illiger, 1801)

Material: 98 (1); 101 (4).

Biology. It is found in mixed and deciduous forests.

*Dasytes niger (Linnaeus, 1760)

Material: 24 (3); 89 (1).

Biology. This is a common species. It is found in mixed and deciduous forests.

Malachius bipustulatus (Linnaeus, 1758) Literature data: Levkovich and Levkovich (2006).

*Glischrochilus quadripunctatus (Linnaeus, 1758)

Material: 43 (1); 53 (2); 54 (1); 102 (2).
Material: 102 (1).

Biology. This is a common species. It is found in mixed and deciduous forests.

\section{Family MONOTOMIDAE Laporte, 1840}

* Carpophilus hemipterus (Linnaeus, 1758)

Material: 98 (1).

Biology. It is found in deciduous forests.

* Rhizophagus fenestralis (Linnaeus, 1758)

Material: 54 (1); 73 (1); 98 (2); 99 (2); 101 (9); 111 (1).

Biology. It lives in deciduous forests. It is found under the bark. It is believed to live in association with Scolytinae (Drost and Heijerman 2017).

\section{Family NITIDULIDAE Latreille, 1802}

* Cryptarcha strigata (Fabricius, 1787)

Material: 3 (2); 4 (3); 6 (1); 8 (2); 9 (3); 10 (4); 14 (3); $16(11) ; 18(1) ; 20(2) ; 22(2) ; 24(2) ; 30(1) ; 33(4) ; 34$ (16); 35 (7); 36 (1); $37(3) ; 39(1) ; 40(2) ; 42(2) ; 43(2) ; 45$ (1); 46 (1); 54 (1); $56(3) ; 60$ (10); 61 (4); 68 (1); 73 (2); 74 (1); 78 (5); 79 (1); 84 (3); 86 (18); 87 (7); 88 (9); 89 (13); 91 (19); 95 (1); 97 (6); 98 (14); 99 (44); 100 (2); 101 (2); 102 (2); 105 (8); 106 (24); 108 (2); 109 (4); 110 (3); 111 (18).

Biology. This is a common species, which, with a larger number, was found in oak and aspen forests. It is quite common in pine forests and mixed forests. The peak population was observed in early June (Ruchin et al. 2021).

* Cryptarcha undata (G.-A. Olivier, 1790)

Material: 7 (2); 8 (1); 9 (1); 14 (3); 15 (1); 16 (1); 28 (1); 33 (2); 34 (1); 73 (6); 86 (1); 91 (1); 96 (1); 97 (1); 98 (1); 99 (4); 111 (7).

Biology. It is a common species with low abundance. It lives in mixed and deciduous forests.

* Glischrochilus grandis (Tournier, 1872)

Material: 1 (9); 3 (8); 4 (4); 5 (5); 6 (11); 7 (16); 8 (47); 9 (24); 10 (103); 11 (4); 12 (13); 14 (12); 15 (10); 21 (1); 26 (1); 33 (31); 34 (21); 35 (4); 43 (20); 47 (2); 49 (3); 50 (7); 52 (2); 53 (3); 55 (30); 54 (27); 56 (12); 67 (1); 68 (1); 73 (8); 74 (4); 75 (4); 82 (1); 83 (1); 85 (10); 86 (8); 87 (3); 90 (5); 92 (2); 93 (13); 94 (3); 95 (3); 96 (68); 97 (94); 98 (775); 99 (774); 100 (48); 101 (85); 102 (44); 103 (51); 104 (1); 107 (1); 108 (21); 109 (101); 110 (108); 111 (82); 114 (9).

Biology. This is a common species, sometimes it can be numerous. It lives in deciduous and mixed forests (Ruchin et al. 2021).

* Glischrochilus hortensis (Geoffroy, 1785)

Material: 43 (1); 48 (1); 52 (1); 55 (3); 56 (2); 57 (1); 87 (1); 98 (3); 99 (5); 101 (1); 102 (1); 109 (3); 110 (1).

Biology. This is a common species, regularly found in deciduous and mixed forests (Ruchin et al. 2021).

Biology. It is a constantly occurring species in crown traps. Its population is usually lower than the one of other Nitidulidae species. 
*Glischrochilus quadrisignatus (Say, 1835)

Material: 3 (2); 7 (1); 8 (2); 9 (2); 41 (3); 42 (1); 55 (3); 85 (3); 93 (1); 101 (1).

Biology. This is a North American dispersing species (Keszthelyi 2012). It is currently known from many regions of Russia (Orlova-Bienkowskaja 2019). It is often found on rotting fruit, on carrion and in manure, in corn, on sapbearing trees (Price and Young 2006). In the Republic of Mordovia, this species is regularly caught in natural ecosystems, in forests of various types (Ruchin et al. 2021).

* Soronia grisea (Linnaeus, 1758)

Material: 9 (1); 18 (1); 22 (3); 24 (3); 28 (2); 30 (1); 33 (1); 34 (1); 38 (1); 45 (1); 50 (1); 51 (1); 54 (2); 56 (1); 61 (1); 67 (1); 68 (3); 86 (2); 88 (1); 89 (1); 91 (2); 95 (1); 96 (7); 97 (14); 98 (29); 99 (33); 100 (1); 101 (1); 104 (2); 105 (3); 106 (4); 108 (2); 110 (4); 111 (2).

Biology. This is a common species, regularly found in deciduous and mixed forests (Ruchin et al. 2021).

\section{Family COCCINELLIDAE Latreille, 1807}

Adalia decempunctata (Linnaeus, 1758)

Literature data: Pronina (2010).

Material: 109 (1).

Biology. It is recorded in deciduous and mixed forests. It accidentally falls into the crown traps.

Calvia decemguttata (Linnaeus, 1767)

Literature data: Pronina (2010).

Material: 102 (2).

Biology. It is recorded in mixed forests. It accidentally falls into the crown traps.

Calvia quatuordecimguttata (Linnaeus, 1758)

Literature data: Levkovich and Levkovich (2006);

Pronina (2010).

Material: 50 (1); 109 (1).

Biology. It is recorded in deciduous and mixed forests in spring. It accidentally falls into the crown traps.

* Coccinella magnifica (L. Redtenbacher, 1843)

Material: 100 (1); 104 (1).

Biology. It is recorded in deciduous forests. It accidentally falls into the crown traps.

\section{Halyzia sedecimguttata (Linnaeus, 1758)}

Literature data: Levkovich and Levkovich (2006); Pronina (2010).

Material: 111 (1).

Biology. It was caught in the spring on the edge of a deciduous forest. It accidentally falls into the crown traps.

\section{Harmonia quadripunctata (Pontoppidan, 1763)}

Literature data: Pronina (2010).

Material: 56 (1).

Biology. It is recorded in a pine forest with birch and linden. It accidentally falls into the crown traps.
Mysia oblongoguttata (Linnaeus, 1758)

Literature data: Pronina (2010).

Material: 43 (1); 54 (1).

Biology.It was recorded in spring in mixed forests. It accidentally falls into the crown traps.

\section{Oenopia conglobata (Linnaeus, 1758)}

Literature data: Pronina (2010).

Material: 48 (1).

Biology. It was recorded in a pine forest with birch, linden and maple trees. It accidentally falls into the crown traps.

\section{Sospita vigintiguttata (Linnaeus, 1758)}

Literature data: Pronina (2010).

Material: 85 (1).

Biology. It was recorded on the edge of a deciduous forest. It accidentally falls into the crown traps.

\section{Family MYCETOPHAGIDAE Leach, 1815}

*Litargus connexus (Geoffroy, 1785)

Material: 6 (1); 98 (1).

Biology. It inhabits deciduous and mixed forests, clearings, and edges.

\section{Family MELANDRYIDAE Leach, 1815 \\ *Phloiotrya subtilis (Reitter, 1897) \\ Material: 87 (1). \\ Biology. It is found in mixed forests.}

\section{Family TENEBRIONIDAE Latreille, 1802}

Lagria hirta (Linnaeus, 1758)

Literature data: Levkovich and Levkovich (2006);

Dobrolyubova (2013).

Material: 65 (1); 86 (1).

Biology. his is one of the most common and numerous species. It flies in late May-July. Beetles feed on flowering plants in meadows, edges and forest clearings. It is rarely caught in crown traps, as it is usually found on the grass.

\section{Family OEDEMERIDAE Latreille, 1810}

*Chrysanthia geniculata (W.L.E. Schmidt, 1846)

Material: 33 (1).

Biology. It is found on the edge of a deciduous forest. It is often found on flowering plants.

Chrysanthia viridissima (Linnaeus, 1758)

Literature data: Anufriev et al. (1999); Levkovich and Levkovich (2006).

Material: 57 (1).

Biology. It is found at the edge of a clearing in a mixed forest.

* Oedemera podagrariae (Linnaeus, 1767)

Material: 40 (1).

Biology. It is found on the edge of a deciduous forest. 


\section{Family CERAMBYCIDAE Latreille, 1802}

Aromia moschata (Linnaeus, 1758)

Literature data: Dyukin (1912); Levkovich and Levkovich (2006).

Material: 1 (7); 14 (1); 19 (1); 32 (1); 61 (2); 76 (1).

Biology. It is a local species of old-growth moist deciduous forest of the region. Beetles fly in June-August, they are found on flowering herbaceous plants. Larvae develop in the basal part of the trunks of different types of willows, they do not settle in withered trees.

Chlorophorus herbstii (Brahm, 1790)

Literature data: Dyukin (1912).

Material: 63 (1).

Biology. It is found in deciduous forest. In such biotopes, it is quite common.

*Chlorophorus varius (Müller, 1766)

Material: 40 (1).

Biology. It is found on the edge of a deciduous forest.

Leptura quadrifasciata (Linnaeus, 1758)

Literature data: Dyukin (1912); Levkovich and Levkovich (2006).

Material: 5 (2); 10 (2); 11 (6); 18 (1); $19(6) ; 22$ (2); 23 (1); 26 (6); 29 (1); 32 (1); 40 (1); 61 (4); 63 (1); 65 (2); 66 (1); 68 (1); 79 (2); 81 (5); 107 (5); 114 (1).

Biology. It inhabits deciduous and mixed forests, clearings, and edges. Beetles fly in June and July. Thy are found on flowering plants of Umbelliferae.

Leptura thoracica (Creutzer, 1799)

Literature data: Dyukin (1912); Red Data Book of Penza Region (2019)

Material: 1 (2); 4 (2); 5 (6); 19 (11); 23 (2); 26 (13); 32 (2); 40 (1); 41 (1); 42 (3); 48 (2); 57 (1); 58 (3); 61 (2); 66 (5); 76 (1); 80 (1); 81 (2); 107 (3).

Biology. The species lives in deciduous, mixed and floodplain forests. It flies in June-July. The larvae develop in the rotten wood of deciduous trees, for example, they were found in the fallen rotten trunk of a hanging birch (Betula pendula Roth.).

Lepturalia nigripes (De Geer, 1775)

Literature data: Dyukin (1912).

Material: 5 (1); 91 (1).

Biology. It inhabits birch forests and light deciduous forests. Beetles fly in May-June. Single specimens were found on flowering plants of Umbelliferae.

* Mesosa myops (Dalman, 1817)

Material: 32 (3).

Biology. It is found in mixed and deciduous forests, in pine forests with an admixture of birch (Ruchin and Egorov 2018 b). In studies region, it was found in deciduous forests.

\section{Necydalis major (Linnaeus, 1758)}

Literature data: Dyukin (1912); Red Data Book of Penza Region (2019); Levkovich and Levkovich (2006).
Material: 25 (1); 27 (1); 40 (1); 58 (1); 65 (1); 66 (3); $71(1) ; 76(3)$.

Biology. It inhabits deciduous and mixed forests. It is rarely found on flowering plants, but it is often lured into crown traps. The larvae develop in the wood of Salix sp. and other deciduous trees.

* Obrium cantharinum (Linnaeus, 1767)

Material: 1 (2); 11 (1); 18 (1); 23 (1); 27 (3); 58 (1); 63 (1); 79 (2); 84 (1).

Biology. It is a rather secretive species, its distribution is confined to old aspen forests, and it inhabits poplar stands in localities (Ruchin and Egorov 2018b). It is possible to study the distribution of this species well with the help of crown traps.

Phymatodes testaceus (Linnaeus, 1758)

Literature data: Dyukin (1912).

Material: 23 (2); 30 (1); 54 (1); 87 (3); 90 (1); 100 (1); 103 (1); 105 (1).

Biology. It inhabits oak forests and mixed forests. Beetles fly in the evening in May-June. The species is local, often found, the larvae develop in the dead oak wood.

\section{Plagionotus detritus (Linnaeus, 1758)}

Literature data: Dyukin (1912).

Material: 58 (1); 77 (1); 100 (1).

Biology. It inhabits oak forests and mixed forests. Beetles fly in June-July. The larvae develop in the dead tree-blue oak and wood logs.

\section{Purpuricenus globulicollis (Dejean, 1839)}

Literature data: Polumordvinov and Glebov (2010); Red Data Book of Penza Region (2019); Ruchin and Egorov (2019).

Material: 60 (2).

Biology. The species was recorded on the edges of deciduous and mixed forests bordering willows in floodplains. It is very rare and local in the region, active from the end of May to the end of July. The larvae develop in the branches of deciduous trees. The use of crown traps with beer gives good results for studying the distribution and abundance of this species.

\section{Purpuricenus kaehleri (Linnaeus, 1758)}

Literature data: Dyukin (1912); Polumordvinov and Glebov (2010); Red Data Book of Penza Region (2019).

Material: 2 (1); 3 (14); 6 (1); 7 (6); 10 (1); 14 (1); 25 (2); 27 (11); 32 (4); 40 (4); 42 (14); 58 (1); 59 (2); 60 (26); 61 (44); 73 (9); 76 (1); 79 (1); 81 (1); 83 (1).

Biology. Previously, it was considered a rather rare and local species, known from the floodplain oaks and willows of the Sura River. New data from crown traps show a wider distribution of the species in the region. Beetles are found from May to July. The larvae develop in the trunks and branches of dying deciduous trees. 
Rhagium inquisitor (Linnaeus, 1758)

Literature data: Dyukin (1912).

Material: 43 (1).

Biology. It inhabits pine and mixed forests. Beetles fly in July-August, sometimes they can be found under the bark of pine stumps.

Rhagium mordax (De Geer, 1775)

Literature data: Dyukin (1912); Levkovich and Levkovich (2006).

Material: 22 (1); 48 (2); 55 (2); 56 (4); 57 (1); 87 (1); 90 (8); 97 (2); 98 (1); 99 (2); 101 (36); 102 (15); 103 (3); 104 (1); 109 (5); $110(3) ; 111(5)$.

Biology. It inhabits deciduous and mixed forests. Beetles fly in May-August. The larvae develop directly under the bark of dead trees. The species flies is well lured to the bait with beer and sugar.

\section{Ropalopus macropus (Germar, 1823)}

Literature data: Dyukin (1912).

Material: 90 (2).

Biology. It is a new find in a mixed forest. It is more typical for deciduous forests.

Rutpela maculata (Poda von Neuhaus, 1761)

Literature data: Dyukin (1912); Levkovich and Levkovich (2006).

Material: 17 (1); 19 (4); 26 (1); 27 (1); 48 (1); 76 (1); 81 (2); 107 (1).

Biology. It is a common species for mixed forest. In nature, it is more common on flowering plants of different families. It is well lured to the crown traps.

Spondylis buprestoides (Linnaeus, 1758)

Literature data: Dyukin (1912); Levkovich and Levkovich (2006).

Material: 23 (1).

Biology. It inhabits pine forests and mixed forests. It is a local species, but sometimes found in big numbers. Beetles fly in June-July. It falls accidently into crown traps.

\section{Stenocorus meridianus (Linnaeus, 1758)}

Literature data: Dyukin (1912).

Material: 21 (1); 32 (1); 58 (3); 60 (1); 61 (5); 80 (1).

Biology. It inhabits old deciduous forests, edges and adjacent meadows, forest parks. It is not uncommon, but occurs only occasionally, more often on flowering plants of Umbelliferae.

\section{Strangalia attenuata (Linnaeus, 1758)}

Literature data: Dyukin (1912); Levkovich and Levkovich (2006).

Material: 84 (1).

Biology. It inhabits deciduous and partly mixed forests. It is a common species. It flies in June-July. Larvae develop in deciduous trees.

\footnotetext{
*Trichoferus campestris (Faldermann, 1835)

Material: 14 (1); 35 (1); 60 (1).
}

Biology. It is an alien species. Currently, it has spread to many regions of Russia. Over the past 20 years, it has penetrated into various countries in Western Europe, and appeared in North America (Dascãlu et al. 2013; Kadyrov et al. 2016; Pennacchio et al. 2016; Ruchin and Egorov 2018b).

*Xylotrechus antilope (Schoenherr, 1817)

Material: 7 (1); 58 (4); 60 (1); 61 (2).

Biology. It is found in deciduous forests. It is usually found on oak trees (our data).

*Xylotrechus arvicola (Olivier, 1795)

Material: 81 (1).

Biology. It was found on the edge of a deciduous forest. It prefers deciduous trees (our data).

*Xylotrechus pantherinus (Savenius, 1825)

Material: 5 (1).

Biology. The species is a monophage on various species of Salix sp. The larvae develop in healthy or weakened trunks and branches, where they develop deep in the wood. Imagos are often found on Salix sp. (Laugsand et al. 2008; Karpiński et al. 2018).

\section{Family CURCULIONIDAE Latreille, 1802}

Anisandrus dispar (Fabricius, 1792)

Literature data: Sakharov (1947).

Material: 56 (8); 92 (1); 98 (20); 99 (4); 109 (25); 110 (2).

Biology. It inhabits almost all hardwoods - oak, linden, fruit trees. It has two generations per summer. Beetles of the first generation fly in May, the second one flies in the middle of summer.

Curculio glandium (Marsham, 1802)

Literature data: Dobrolyubova (2013).

Material: 7 (1); 67 (1).

Biology. It is found on the edges of mixed and deciduous forest.

Curculio nucum (Linnaeus, 1758)

Literature data: Levkovich and Levkovich (2006).

Material: 29 (5).

Biology. It is found on the edges of deciduous forest.

*Curculio villosus (Fabricius, 1781)

Material: 98 (1).

Biology. It is found on the edges of deciduous forest.

Phyllobius argentatus (Linnaeus, 1758)

Literature data: Levkovich and Levkovich (2006).

Material: 90 (1).

Biology. It is found on the edges of mixed forest.

Phyllobius pyri (Linnaeus, 1758)

Literature data: Levkovich and Levkovich (2006).

Material: 54 (1).

Biology. It is found on the edges of mixed forest. 


\section{Discussion}

The most diverse families were Cerambycidae (24 species) and Elateridae (11 species) (Figure 2). Most of the families were represented in our collections by single species. Species from the families Nitidulidae (3,281 specimens), Scarabaeidae (1,497 specimens), and Cerambycidae (453 specimens) predominated in the traps. The remaining families were represented by less than a hundred specimens, and some - by single individuals only (Figure 3).

In total, 43 of the 97 species found are new to the Penza region. Mainly, these are common species for mixed and deciduous forests and are rarely melted in other ways. Three species (Glischrochilus quadrisignatus, Trogoderma glabrum, and Trichoferus campestris) are alien.

Due to the fact that the fauna of Coleoptera in the Penza region is not sufficiently studied, many of the most common species have not yet been reliably found. It is known that fermental crown traps are often a good additional tool for collecting information about rare and little-known species (their abundance and distribution in the study area). For example, among the species included in the Red Data Book of Penza Region (2019), 4 species were found - Protaetia fieberi, Protaetia speciosissima, Gnorimus variabilis, Purpuricenus globulicollis. The first two species are included in the Red Book of the Russian Federation (List of Objects of the Animal World Listed in the Red Book of the Russian Federation 2020). In the Red Data Book of Penza Region (2019), 6 localities of Protaetia fieberi are indicated for the region, and we have made new notes concerning 48 habitats. There are also 11 localities of Protaetia speciosissima, while our research has proven the existence of this species in another 20 habitats.

The biodiversity of Coleoptera from crown traps differs from those caught in other ways (Barber traps, hand- picking, window traps, and others). Our trapping method allowed us to identify at once a significant number of species that are not often found in nature or lead a secretive lifestyle. Previously, such traps were recommended for use in the study of rare insect species (Ruchin et al. 2020). Different trapping methods, when used correctly, can be an effective tool, for example, in monitoring biodiversity and studying rare insect species that are difficult to detect in other ways.

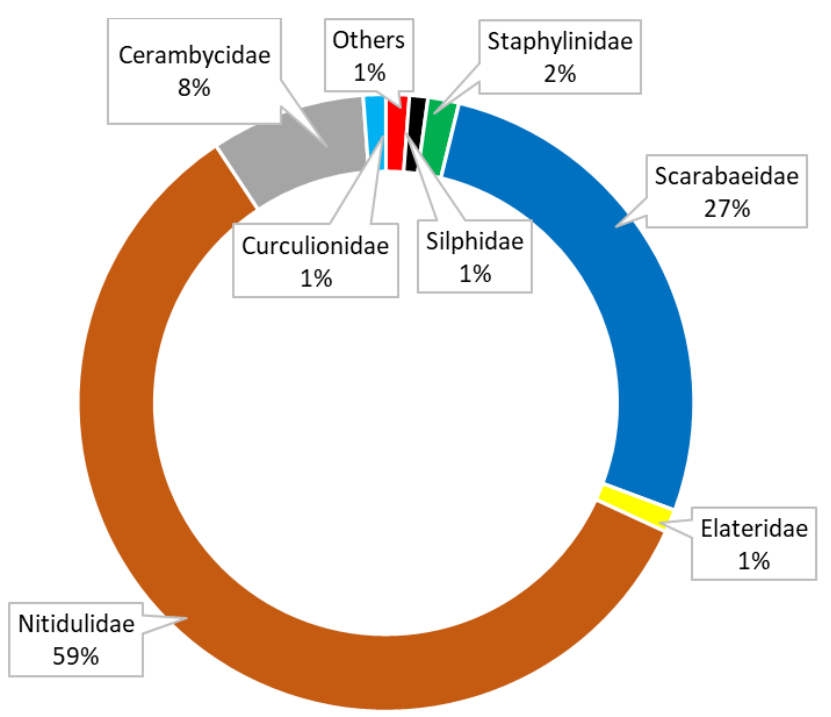

Figure 3. The number of specimens of Coleoptera in separate families registered in traps. Others - Carabidae, Buprestidae, Cantharidae, Dermestidae, Ptinidae, Cleridae, Melyridae, Monotomidae, Coccinellidae, Melandryidae, Mycetophagidae, Tenebrionidae and Oedemeridae

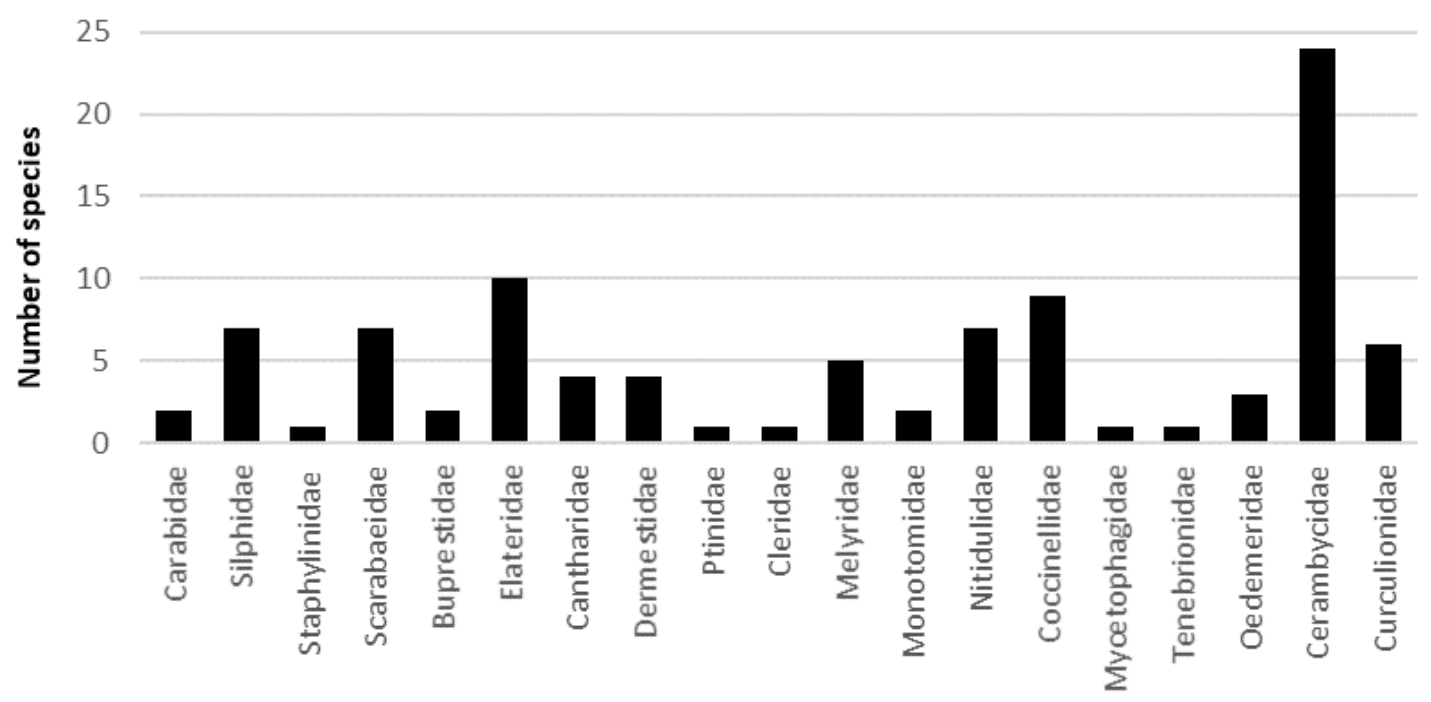

Figure 2. The number of species in the families recorded in the traps 
In conclusion, the biodiversity of Coleoptera that fall into crown traps is significant. Using crown traps, 5,577 beetle specimens were collected and recorded in 20192020. 97 species from 19 families were found, of which 43 species are new to the Penza region. The most diverse families are Cerambycidae (24 species) and Elateridae (11 species). Numerically, species from the families Nitidulidae, Scarabaeidae, and Cerambycidae predominated in the catches. The traps used are well established for studying the diversity of species included in the Red Book of the region (Protaetia fieberi, Protaetia speciosissima, Gnorimus variabilis, Purpuricenus globulicollis). We recommend the use of crown traps with beer and wine for ecological studies of the Coleoptera fauna. This method can be used to study seasonal, biotopic features of the fauna.

\section{REFERENCES}

Ahissa L, Akpatou BK, Bohoussou HK, Kadjo B, Koné I. 2020. Species composition and community structure of terrestrial small mammals in Tanoé-Ehy Swamp Forest (South-East Ivory Coast): Implication for conservation. Nat Conserv Res 5(1): 53-63. DOI: 10.24189/ncr.2020.005.

Alekseev SK, Ruchin AB. 2020. Fauna and abundance of ground beetle (Coleoptera, Carabidae) in pine forests. Entomol Appl Sci Lett 7(1): $1-9$.

Anufriev GA, Bocharov SV, Potanin DV. 1999. About entomofauna of the State Nature Reserve «Privolzhskaya lesostep». Scientific works of the State Nature Reserve «Prisursky» 2: 8-14. [In Russian]

Bardiani M, Tini M, Carpaneto GM, Audisio P, Bussola E, Campanaro A Cini A, Maurizi E, Mason F, Peverieri GS, Roversi PF, Toni I, Chiari S. 2017. Effects of trap baits and height on stag beetle and lower chafer monitoring: Ecological and conservation implications. J Insect Conserv 21(1): 157-168. DOI: 10.1007/s10841-017-9965-3.

Barros RC, Fonseca MG, Jardim MT, Vendramini VE, Damiani BCB, Julio CEA. 2020. Species of Cerambycinae (Insecta, Coleoptera, Cerambycidae) from East Paraná State (Brazil), with new geographic records. Zootaxa 4845(1): 1-25. DOI: 10.11646/zootaxa.4845.1.1.

Bashinskiy IV, Osipov VV. 2019. Sedimentation rate of suspended matter and its chemical composition in beaver water bodies in the State Nature Reserve «Privolzhskaya Lesostep'»(European Russia). Nat Conserv Res 4(3): 54-66. DOI: 10.24189/ncr.2019.046.

Bondarenko AS, Zamotajlov AS, Belyi AI, Khomitskiy EE. 2020. Fauna and ecological characteristics of ground beetles (Coleoptera Carabidae) of the Nature Sanctuaries «Prichernomorskiy» and «Tuapsinskiy» (Russia). Nat Conserv Res 5(3): 66-85. DOI: 10.24189/ncr.2020.032.

Bokhovko EE, Stoiko TG. 2002. Fauna Coleoptera: Problems of ecological rehabilitation of the natural environment of the Russian village. Moscow: Nauchnaya kniga Publ: $80-83$. [In Russian]

Budaev FA, Eremeeva NI, Efimov DA, Zinchenko VK. 2019. Water beetles (Coleoptera: Gyrinidae, Noteridae, Dytiscidae) of the foreststeppe of Kemerovo Region. Far Eastern Entomol 382: 13-24. DOI: $10.25221 /$ fee. 382.3 .

Cicort-Lucaciu AȘ. 2020. Road-killed ground beetles prove the presence of Carabus hungaricus (Coleoptera: Carabidae) in North-Western Romania. Nat Conserv Res 5(3): 134-138. DOI: $10.24189 /$ ncr.2020.035

Danilevsky M. 2020. Catalogue of Palaearctic Coleoptera. Vol. 6/1 Updated and Revised Second Edition. Chrysomeloidea I (Vesperidae, Disteniidae, Cerambycidae). Brill, Leiden-Boston. 712 p.

Danilevsky ML, Ruchin AB, Egorov LV. 2019. Mass collection of two rare Longicorn-species (Coleoptera, Cerambycidae) in Central Russia. Humanity Space 8(9): 1179-1183. DOI: 10.1163/9789004440333.

Dascălu MM, Serafim R, Lindelov A. 2013. Range expansion of Trichoferus campestris (Faldermann) (Coleoptera: Cerambycidae) in Europe with the confirmation of its presence in Romania. Entomol Fenn 24: 142-146. DOI: 10.33338/ef.8981.
Dedyukhin SV. 2020. Phytophagous beetles (Coleoptera: Chrysomelidae and Curculionoidea), protected and recommended for protection in the regions of the Middle Volga and the Urals. Nat Conserv Res 5(2): 1-27. DOI: 10.24189/ncr.2020.013.

de Lima NS, Napiwoski SJ, Oliveira MA. 2020. Human-wildlife conflict in the Southwestern Amazon: Poaching and its motivations. Nat Conserv Res 5(1): 109-114. DOI: 10.24189/ncr.2020.006.

Dmitriev GV. 1926. Scarabaeidae of Penza province (Coleoptera, Scarabaeidae). Definitive tables for the list of Scarabaeidae beetles of the Penza Province. Proceedings of the Penza Society of Lovers of Natural History and Local Lore 10: 1-22. [In Russian]

Dobrolyubova TV. 2013. Additions to the fauna of insects Poperechenskaya steppe and forest-steppe Ostrovosky. Proceedings of the State Nature Reserve «Privolzhskaya lesostep» 3: 139-153. [Russian]

Dodds KJ. 2014. Effects of trap height on captures of arboreal insects in pine stands of northeastern United States of America. Can Entomol 146(1): 80-89. DOI: $10.4039 /$ tce.2013.57.

Drost B, Heijerman T. 2017. Rhizophagus fenestralis, een nieuwe keversoort voor Nederland (Coleoptera: Monotomidae). Nederl Faun Med 48: 115-121.

Dyukin SV. 1912. Barbel beetles of the Penza province (Coleoptera, Cerambycidae). Russ Entomol Rev 12(2): 280-282. [Russian]

Egorov LV, Ruchin AB, Semenov VB, Semionenkov OI, Semishin GB. 2020a. Checklist of the Coleoptera of Mordovia State Nature Reserve, Russia. ZooKeys 962: 13-122. DOI: 10.3897/zookeys.962.54477.

Egorov LV, Ruchin AB, Semishin GB. 2020b. Some data on the Coleoptera fauna in the Mordovia State Nature Reserve. Report 9. Proceedings of the Mordovia State Nature Reserve 24: 61-150. [Russian]

Grubert E. 2018. Relational values in environmental assessment: the social context of environmental impact. Curr Opin Environ Sustain 35: 100-107. DOI: 10.1016/j.cosust.2018.10.020.

Huang CW, Mcdonald RI, Seto KC. 2018. The importance of land governance for biodiversity conservation in an era of global urban expansion. Landsc. Urban Plan 173: 44-50. DOI: 10.1016/j.landurbplan.2018.01.011.

Hooper DU, Chapin III FS, Ewel JJ, Hector A, Inchausti P, Lavorel S, Lawton JH, Lodge DM, Loreau M, Naeem S, Schmid B, Setälä H, Symstad AJ, Vandermeer J, Wardle DA. 2005. Effects of biodiversity on ecosystem functioning: A consensus of current knowledge. Ecol Monogr 75: 3-35. DOI: 10.1890/04-0922.

Feng C, Cao M, Wang W, Wang H, Liu F, Zhang L, Du J, Zhou Y, Huang We, Li J. 2020. Which management measures lead to better performance of China's protected areas in reducing forest loss?. Sci Total Environ 3: 142895. DOI: 10.1016/j.scitotenv.2020.142895.

Frolov A. 2013. Little known Orphninae (Coleoptera, Scarabaeidae) collected by the Madagascan expeditions of the California Academy of Sciences. Biodivers 1: e1016. DOI: 10.3897/BDJ.1.e1016.

Iwan D, Löbl I. 2020. Catalogue of Palaearctic Coleoptera. Vol. 5. Revised and Updated Second Edition. Tenebrionoidea. Brill, LeidenBoston. 945 p. DOI: 10.1163/9789004434998.

Jalas I. 1960. Eine leichtgebaute, leichttransportable Lichtreuse zum Fangen von Schmetterlingen. Ann Entomol Fenn 26: 44-50.

Kadyrov AK, Karpiński L, Szczepański WT, Taszakowski A, Walczak M. 2016. New data on distribution, biology, and ecology of longhorn beetles from the area of west Tajikistan (Coleoptera, Cerambycidae). Zookeys 606: 41-64. DOI:10.3897/zookeys.606.9190.

Karpiński L, Szczepański WT, Boldgiv B, Walczak M. 2018. New data on the longhorn beetles of Mongolia with particular emphasis on the genus Eodorcadion Breuning, 1948 (Coleoptera, Cerambycidae). Zookeys 739: 107-150. DOI: 10.3897/zookeys.739.23675.

Kazantsev SV, Egorov LV, Ruchin AB. 2019. Discovery of Lopheros lineatus (Gorham, 1883) (Coleoptera, Lycidae) in Mordovia, Central Russia. Entomol Rev 99: 656-659. DOI: 10.1134/S0013873819050099.

Kestemont B. 2019. The bottom-up assessment of threatened species. Nat Conserv Res 4(3): 93-106. DOI: 10.24189/ncr.2019.036.

Keszthelyi S. 2012. Evaluation of flight phenology and number of generations of the four-spotted sap beetle, Glischrochilus quadrisignatus in Europe. Bull Insectology 66 (1): 9-16.

King S, Vardon M, Grantham HS, Eigenraam M, Ferrier S, Juhn D, Larsen T, Brown C, Turner K. 2021. Linking biodiversity into national economic accounting. Environ Sci Policy 116: 20-29. DOI: 10.1016/j.envsci.2020.10.020. 
Kroll AJ, Springford A, Verschuyl J. 2020. Conservation and production responses vary by disturbance intensity in a long-term forest management experiment. Ecol Appl 30(7): e02148. DOI: 10.1002/eap.2148.

Kuritsyn II, Mardensky NA. 1991. Geography of the Penza region. Volga book Publ, Saratov 96 p. [Russian]

Laugsand AE, Olberg S, Reiråskag C. 2008. Notes on species of Cerambycidae (Coleoptera) in Norway. Norw J Entomol 55: 1-6.

Lebyazhinskaya IP. 2012. Ground beetle fauna (Coleoptera, Carabidae) Ostrovosky forest. Proceedings of the State Nature Reserve «Privolzhskaya lesostep» 2: 221-227. [ Russian]

Levkovich EV, Levkovich VG. 2006. Beetles of the Penza region. Izvestiya Penza State Pedagogical University named after V.G. Belinsky 5: 100-104. [Russian]

List of objects of the animal world listed in the Red Book of the Russian Federation. 2020. URL: www.minjust.consultant.ru/documents/45937 [accessed 5.11.2020]

Löbl I., Löbl D. (eds.). 2015. Catalogue of Palaearctic Coleoptera. Vol. 2/1. Revised and updated version. Hydrophiloidea - Staphylinoidea. Brill, Leiden-Boston. 1702 p. DOI: 10.1163/9789004296855.

Löbl I, Löbl D. 2016. Catalogue of Palaearctic Coleoptera. Vol. 3. Revised and updated version. Scarabaeoidea - Scirtoidea Dascilloidea - Buprestoidea - Byrrhoidea. Brill, Leiden-Boston. 983 p.

Löbl I, Smetana A. 2007. Catalogue of Palaearctic Coleoptera. Vol. 4. Elateroidea - Derodontoidea - Bostrichoidea - Lymexyloidea Cleroidea - Cucujoidea. Apollo Books, Stenstrup. 935 p. DOI: $10.1163 / 9789004260894$

Löbl I, Smetana A. 2011. Catalogue of Palaearctic Coleoptera. Vol. 7. Curculionoidea I. Apollo Books, Stenstrup. 373 p. DOI $10.1163 / 9789004260931$

Löbl I, Smetana A. 2013. Catalogue of Palaearctic Coleoptera. Vol. 8. Curculionoidea II. Brill, Leiden-Boston. 700 p. DOI 10.1163/9789004259164.

Mathews F. 2016. From biodiversity-based conservation to an ethic of bio-proportionality. Biol Conserv 200: 140-148. DOI: 10.1016/j.biocon.2016.05.037.

Mellard JP, Audoye P, Loreau M. 2019. Seasonal patterns in species diversity across biomes. Ecology 100(4): e02627. DOI 10.1002/ecy. 2627

Merkl O. 1993. Eucinetoidea, Dascilloidea, Byrrhoidea, Dermestoidea and Bostrichoidea from the Bukk National Park (Coleoptera). The Fauna of the Bukk National Park 1: 105-110.

Myers N, Mittermeier RA, Mittermeier CG, Da Fonseca GA, Kent J. 2000. Biodiversity hotspots for conservation priorities. Nature 403: 853. DOI: $10.1038 / 35002501$.

Nikitsky NB, Schigel DS. 2004. Beetles in polypores of the Moscow region, Russia: Checklist and ecological notes. Entomol Fenn 15: 622. DOI: $10.33338 /$ ef. 84202 .

Orlova-Bienkowskaja MJ. 2019. Inventory on alien beetles of European Russia. Mukhametov G.V., Livny. 882 p. [Russian]

Pennacchio F, Marianelli L, Binazzi F, Francardi V, Paoli F, Griffo R, Roversi PF. 2016. First interception of Trichoferus campestris (Faldermann, 1835) (Coleoptera Cerambycidae Cerambycinae) in Italy. Redia 99: 59-62. DOI: 10.19263/REDIA-99.16.06.

Philip, TK, Whorrall KA, Gearner OM, Huchet JB. 2020. A new genus of spider beetle (Coleoptera, Ptinidae) from western Peru. Zookeys 934: 81-91. DOI: 10.3897/zookeys.934.38670.

Polevoi AV, Humala AE, Kulebyakina EV, Kutenkova NN. 2018. First records of two remarkable Coleoptera species Cucujus cinnaberinus and Metoecus paradoxus (Coleoptera: Cucujidae, Rhipiphoridae) from the Republic of Karelia (Russia). Nat Conserv Res 3(3): 98-102. DOI: $10.24189 /$ ncr.2018.036.

Polumordvinov OA, Glebov IV. 2010. Purpuricenus globulicollis Dejean in Mulsant, 1840 (Coleoptera, Cerambycidae) - a new species for the fauna of barbel beetles of the Penza region. Entomological and parasitological studies in the Volga region 8: 107-108. [In Russian]

Polumordvinov OA, Monakhov AM. 2003. Rare and requiring protection coleoptera (Insecta, Coleoptera) on the territory of the Penza region. I (Coleoptera: Carabidae, Dytiscidae, Lucanidae, Scarabaeidae). In: Protection of Flora and Fauna of the Volga Region and Adjacent territories. PGPU Publ, Penza. 73-76 p. [Russian]

Price MB, Young DK (2006) An annotated checklist of Wisconsin sap and short-winged flower beetles (Coleoptera: Nitidulidae, Kataretidae). Insecta Mundi 20(1-2): 68-84.
Prokin AA, Sazhnev AS, Philippov DA. 2019. Water beetles (Insecta: Coleoptera) of some peatlands in the North Caucasus. Nat Conserv Res 4(2): 57-66. DOI: 10.24189/ncr.2019.016.

Pronina IG. 2010. Materials for the coccinellid fauna (Coleoptera, Coccinellidae) of the Penza region. In: Zoological Research in the Regions of Russia and in Adjacent Territories. Progress Publ. P, Saransk 90-92 p. [Russian]

Red Data Book of Penza Region. 2019. Vol. 2. Animals. Voronezh: 264 pp. [In Russian].

Redolfi De Zan L, Bardiani M, Antonini G, Campanaro A, Chiari S, Mancini E, Maura M, Sabatelli S, Solano E, Zauli A, Sabbatini PG, Roversi PF. 2017. Guidelines for the monitoring of Cerambyx cerdo. Nat Conserv 20. 129-164 DOI: 10.3897/natureconservation.20.12703.

Robin L. 2011. The rise of the idea of biodiversity: crises, responses and expertise. Quaderni 76: 25-37. DOI: 10.4000/quaderni.92.

Rozhnov VV, Lavrinenko IA, Razzhivin VY, Makarova OL, Lavrinenko OV, Anufriev VV, Babenko AB, Bizin MS, Glazov PM, Goryachkin SV, Kolesnikova AA, Matveyeva NV, Pestov SV, Petrovskii VV, Pokrovskaya OB, Tanasevich AV, Tatarinov AG. 2019. Biodiversity revision of a large arctic region as a basis for its monitoring and protection under conditions of active economic development (Nenetsky Autonomous Okrug, Russia). Nat Conserv Res 4(2): 1-28. DOI: $10.24189 /$ ncr.2019.015. [Russian]

Ruchin AB, Alekseev SK, Khapugin AA. 2019a. Post-fire fauna of carabid beetles (Coleoptera, Carabidae) in forests of the Mordovia State Nature Reserve (Russia). Nat Conserv Res 4: 11-20. DOI: 10.24189/ncr.2019.009.

Ruchin AB, Egorov LV. 2018a. Discovery of Allonyx quadrimaculatus (Schaller, 1783) (Coleoptera Cleridae Clerinae) in Russia. Redia 101: 143-146. DOI: 10.19263/REDIA-101.18.19.

Ruchin AB, Egorov LV. 2018b. Fauna of longicorn beetles (Coleoptera: Cerambycidae) of Mordovia. Russ Entomol J 27(2): 161-177. DOI: 10.15298/rusentj.27.2.07

Ruchin AB, Egorov LV. 2018c. Leptura aurulenta (Coleoptera, Cerambycidae), a new record of a very rare species in Russia. Nat Conserv Res 3(1): 88-91. DOI: 10.24189/ncr.2018.003.

Ruchin AB, Egorov LV. 2019a. Contribution to the study of the Cantharoidea (Coleoptera: Drilidae, Lycidae, Lampyridae, Cantharidae) in the Republic of Mordovia (Russia). Entomol Appl Sci Lett 6(2): 1-12.

Ruchin AB, Egorov LV. 2019b. New records of Purpuricenus globulicollis Dejean, 1840 (Coleoptera, Cerambycidae) from Central Russia. Humanity Space 8(9): 1198-1201.

Ruchin AB, Egorov LV, Semishin GB. 2018. Fauna of click beetles (Coleoptera: Elateridae) in the interfluve of Rivers Moksha and Sura, Republic of Mordovia, Russia. Biodiversitas 19(4): 1352-1365. DOI: 10.13057/biodiv/d190423.

Ruchin AB, Egorov LV, Khapugin AA. 2021. Seasonal activity of Coleoptera attracted by fermental crown traps in forest ecosystems of Central Russia. Ecol Quest 32(1): 37-53. DOI: 10.12775/EQ.2021.004.

Ruchin AB, Egorov LV, Khapugin AA, Vikhrev NE, Esin MN. 2020. The use of simple crown traps for the insects collection. Nat Conserv Res 5(1): 87-108. DOI: $10.24189 /$ ncr.2020.008.

Ruchin AB, Egorov LV, Semishin GB. 2019b. Ladybird beetles fauna (Coleoptera: Coccinellidae) of the Republic of Mordovia, Russia. Biodiversitas 20(2): 316-327. DOI: 10.13057/biodiv/d200203

Ruchin AB, Egorov LV, Sazhnev AS, Polumordvinov OA, Ishin RN. 2019c. Present distribution of Protaetia fieberi (Kraatz, 1880) (Insecta, Coleoptera, Scarabaeidae) in the European part of Russia. Biharean Biol 13(1): 12-16.

Ruchin AB, Khapugin AA. 2019. Red data book invertebrates in a protected area of European Russia. Acta Zool Acad Sci Hung 65(4): 349-370. DOI: 10.17109/AZH.65.4.349.2019

Rukavina I, Kostanjšek F, Jelaska SD, Pirnat A, Šerić Jelaska L. 2018. Distribution and habitat suitability of two rare saproxylic beetles in Croatia - a piece of puzzle missing for South-Eastern Europe. iForest 11: 765-774. DOI: 10.3832/ifor2753-011.

Sakharov NL. 1947. Dangerous insects of the Lower Volga region.OGIZ Publ., Saratov 424 p. [Russian]

Salnitska M., Solodovnikov A. 2019. Rove beetles of the genus Quedius (Coleoptera, Staphylinidae) of Russia: A key to species and annotated catalogue. Zookeys 847: 1-100. DOI: 10.3897/zookeys.847.34049.

Sazhnev AS, Pestov SV, Philippov DA. 2019. Review of leaf-beetles (Coleoptera: Chrysomelidae) in mires of Vologda Region, Russia. 
Proceedings of the Mordovia State Nature Reserve 22: 160-174. [Russian]

Sergeev ME. 2020. Species composition and biotopic distribution of leaf beetles (Coleoptera: Megalopodidae, Chrysomelidae) in the SikhoteAlin State Nature Reserve (Russia). Nat Conserv Res 5(2): 80-88. DOI: $10.24189 /$ ncr.2020.020.

Storozhenko SY, Lelej AS, Kurzenko NV, Tshistjakov YA, Sidorenko VS. 2002. Insect biodiversity of the Russian Far East. Far Eastern Entomol 109: 1-28.

Tomaszewska W, Egorov LV, Ruchin AB, Vlasov DV. 2018. First record of Clemmus troglodytes (Coleoptera: Coccinelloidea, Anamorphidae) for the fauna of Russia. Nat Conserv Res 3(3): 103-105. DOI: $10.24189 /$ ncr. 2018.016

Touroult J, Witté I. 2020. Beer, wine, or fruit juice: which is best? A case study of bait efficiency to sample saproxylic beetles (Coleoptera) in an oak woodland. Coleopterists Bull 74(4): 763-771. DOI: 10.1649/0010-065X-74.4.763.

Uwalaka NO, Muoghalu JI, Osewole AO. 2018. Species diversity and successional dynamics in the secondary forest of Obafemi Awolowo University Biological Gardens Ile-Ife, Nigeria. Nat Conserv Res 3(1): 21-34. DOI: $10.24189 /$ ncr.2018.002.

Wang W, Feng C, Liu F, Li J. 2020. Biodiversity conservation in China: A review of recent studies and practices. Environ Sci Ecotechnol 2: 100025. DOI: 10.1016/j.ese.2020.100025.

Zemoglyadchuk AV, Ruchin AB, Egorov LV. 2020. An annotated checklist of the tumbling flower beetles (Coleoptera, Mordellidae) of the Republic of Mordovia, with a short review of the family in European Russia. Entomol Rev 100(6): 771-787. DOI: $10.1134 / \mathrm{S} 0013873820060068$. 